\title{
Introduction to 'Learning the Future Otherwise: Emerging Approaches to Critical Anticipation in Education'
}

Sarah Amsler ${ }^{1}$ and Keri Facer ${ }^{2}$

In November 2015, a gathering was convened in Italy to explore how to 'improve the resilience of societies facing threats from a global proliferation of agents and forces by articulating uncertainties through anticipatory processes' (Project Anticipation 2015). ${ }^{1}$ The First International Conference on Anticipation drew researchers and practitioners from around the world and across disciplines to explore how the future is made into an active part of the historical present, and to debate the cultural, ecological, economic, epistemological, political and social consequences of the 'anticipatory processes' which are shaping futureoriented action today (Poli 2017).

While concern for the future and futurity has been an historical constant in the arts, humanities, sciences and social sciences -for example, in utopian experimentation and predictive science - the newer field of Anticipation Studies focuses on how human consciousness has evolved 'from prediction to forecast to foresight and eventually to anticipation and shaping the future' (Motti 2017). ${ }^{2}$ Whereas attempts to predict organisational dynamics, political developments, financial behaviour, economic demands or ecological disasters aspire to eliminate risks of uncertainty, and foresight aims to equip actors with insights into multiple possibilities, anticipation assumes an active and critically reflective interaction with futures that are unknowable. Anticipation Studies, therefore, is less concerned with the future as an object of study than in the emergence of new forms of timeconsciousness and anticipatory practices which enable people to engage with ideas of the future as a resource to interrogate the complexity and possibilities of the present (Miller 2010; Poli 2017)

The question of how to understand and interact with the future is particularly present in education. Organised learning, always for specific purposes, is an intrinsically future-oriented activity (Facer 2011). However, the relationship between education and the future is not always an anticipatory one in which ideas of the future and the forms of time-consciousness that are used to undergird educational practice are subject to critical reflection. Indeed, the education-future relation is often understood instrumentally. Curricula are designed to shape, legitimise and produce a desired future (such as productive capitalism or social democracy); pedagogies are developed to minimise the possibility of particular futures (such as homophobic and racist behaviours, or anti-establishment dissent); and imagined futures are appropriated to rationalise educational policies and agendas in the present (e.g., as imageries of economic hardship are deployed to justify the withdrawal of funding for education, and imageries of climate catastrophe are evoked to justify the teaching of 'sustainable development').

\footnotetext{
${ }^{1}$ Associate Professor in Education, School of Education, University of Nottingham, Dearing Building, Nottingham, UK, sarah.amsler@nottingham.ac.uk (corresponding author).

2 Professor of Educational and Social Futures, Graduate School of Education, University of Bristol, Helen Wodehouse Building, 35 Berkeley Square, Clifton, Bristol, UK, Keri.Facer@bristol.ac.uk.
} 
The limitations of this instrumental orientation of education toward the future have been articulated in educational philosophy since Dewey and Arendt. More recently, scholars such as Deborah Osberg (2010) and Gert Biesta (2007) have argued that such an orientation is profoundly uneducational, preventing, as it does, attention to the new beginnings and unforeseen possibilities that emerge in the encounter between each human being and what has gone before. Indeed, it is reasonable to argue that an educational practice oriented to the achievement of foreseeable futures is likely to produce a significant societal risk by reducing the diversity of ways of knowing and being that are essential for adapting to unforeseeable circumstances. Framing education within a predictive mindset, in other words, is both uneducational and likely to fail to achieve its stated intention of achieving future societal flourishing.

Understanding how we might disrupt this instrumental framing of education as servant of a predictable future is therefore an urgent concern. The essays in this special issue of Futures, all initially presented at the Anticipation conference, offer alternative understandings of how the relationship between education and the future can be actively 'co-constituted' in many different educational contexts. While the papers are situated within different intellectual traditions and geographical locations, together they call on educators to respond radically and imaginatively to the critical, interconnected crises of our age: the human and ecological damages of anthropogenic climate change, the intensification and globalisation of capitalist imaginaries and modes of production, the 'datafication' of human relations, and the division and militarisation of populations around the world. While these are sometimes discussed as problems in educational circles (Bassey, 2011; Smith, 2017), the papers in this issue focus specifically on how different forms of time consciousness, particularly about the future, shape the role of educational practices in their resolution. They have a particular interest in what is variously described as the 'capture', 'foreclosure' and 'colonisation' of the future, and in methods for prising and keeping new possibilities open.

Rather than taking the future for granted as an empirical or normative orientation or an object of analysis, therefore, the authors conceptualise it as a construction site, an organisational resource, a design project and a political struggle, and articulate education as a site and mode of temporal intervention. The papers reveal how different types of 'anticipatory regime' (Adams et al., 2009) produce destructive educational systems which not only instrumentalise the future in the service of here-and-now social control but dispossess people of the capacity to give form to and transform their worlds (Gutiérrez Aguilar, Navarro Trujillo and Linsalata 2016). However, far from remaining in the moment of negative critique, they also illustrate how dynamic relations between education and the future are and can be created. They show how the education-future relation can become critically anticipatory in diverse spaces including school classrooms, university curricula, museums, educational organisations, national and international educational policies and social movements.

The first paper, 'Contesting anticipatory regimes in education: exploring alternative educational orientations to the future', tackles these questions by juxtaposing three approaches to futurity which co-exist in education today: the 'anticipatory regime', 'emergentist' and 'inventionalist' models of learning. Faced with the challenge of 
overcoming politically constructed hopelessness in advanced capitalist societies (Amsler 2015; Dinerstein 2014), Sarah Amsler and Keri Facer ask what a 'socially and ecologically progressive educational project [might] look like at the present conjuncture, in which collective futures cannot be adequately comprehended, predicted or controlled; in a context which undermines the very proposition that people can successfully learn in the present'. Drawing on critical theories of possibility from Ernst Bloch, John Dewey, Paulo Freire and Deborah Osberg, they argue that education should expand the 'individual and collective capability for active-creative engagement with the future', and the capacity to work in the contradictions of that region of possibility which Bloch calls the 'not yet'. This is difficult, however, where educational policy and practice are parts of anticipatory regimes in which the goal is to optimise present advantages vis-à-vis algorithmically calculated possibilities. Their focus in the paper is the opening up of possibilities of resistance to the datafication and targeting of children's knowledge, 'evidence-based' and 'data-driven' educational governance, key performance indicators and state audit in UK schooling. Drawing on these examples, they illustrate how education is captured by practices of 'abduction' (Adams et al. 2009), or adjustments to futures which are constructed as inevitable, and divested of the democratic possibility to deliberate and co-create desired alternatives. Amsler and Facer highlight critical alternatives to these repressive forms of anticipation which exist beyond hegemonic educational discourses. They point to perspectives offered by autonomous learning projects which are embedded in struggles to create and defend non-capitalist forms of common life, and which aim not to interact with anticipated futures but to engage the future as a space of 'plural and concrete possibilities, utopian and realist at one time, and constructed in the present by means of activities of care' (Santos 2014, p. 182).

Resisting the foreclosure of the future is a central concern of many of the papers in this issue. In 'Near Future School: world building beyond a neoliberal present with participatory design fictions', for example, James Duggan, Joseph Lindley and Sarah McNicol explore how methods of 'participatory design fiction' can support young people to develop concepts that form the basis for the performance of new realities. (Design fiction brings together science, science fiction and design in order to build 'prototypes' of future; see also Sandra Kemp, this issue). Their paper reflects on a project which aimed to use this methodology to enable young people to see beyond the diminished scenarios of the future which are constructed by educational policy makers and teachers, and to design alternative futures of co-operative school governance and radical democracy. Duggan and his colleagues begin by reflecting on the original utopian intentions of 'Building Schools for the Future' (2004-2010), a UK government programme that aimed to create school environments that could improve pupil attainment whilst being adapted and adaptable to present and future pedagogical and technological changes, and preparing pupils for the $21^{\text {st }}$ century'. However, they suggest that the democratic potential of the design has already been colonised by 'neoliberalising forms of future foreclosure', specifically the 'performance management' of learning and school life itself. This was epitomised in the school by the display of a large 'performance matrix' that publicised students' academic achievements and failures. In this 'Near Future School', participatory design fiction was introduced as an experiment in 'speculative governance' which invited students to reconsider the complex rationalities, technologies, discourses and 
practices of their educational reality. The researchers aimed to 're-imagine the matrix within an imaginary world, one in which the matrix and the school were not organised according to the disciplinary power of neoliberal governance and performative structures but rather an alternative and affirmative form of governance'. Yet while the young people could articulate possible educational futures, they lacked the conceptual, affective and political tools to 'think beyond or challenge a neoliberalising present', and thus took their hopelessness with them through time. This raises important questions about which genres, discourses, theories and forms of design might provide such tools, and about how methods of design fiction might shift from 'designing solutions to problems' into a more playful relation with the future in the 'convening of a discursive space' for ongoing debate in participatory governance.

The first papers in this issue concentrate on educators' everyday experiences of 'neoliberal realism' (Gayá and Brydon-Miller, this issue) and projects to prise open alternative futures in pedagogical practice. Susan Robertson, however, directs her lens towards the global actors, agencies, policies and technologies which are transforming higher education from a public service into a capitalist market - and colonising educational futures in order to succeed. 'Colonising the future: mega-trade deals, education services and global higher education markets' illustrates how the struggle for the future of education is taking place in Australia, New Zealand and the UK through the reconfiguration of the temporal orders of learning and scholarship themselves. This has been driven at the global level since the 1980s by a multinational project to recast higher education as a competitive economic market, equivalent with extractive industries such as (in the example of Australia) iron, coal, oil and natural gas.

Central to this project is the dismantling of the traditional temporality and 'time-future' of the university, which Robertson argues in its ideal-type form creates a kind of 'time-space separate from the boisterous tempo of the outside world' and from the temporality of capital and its exchange. In order to future-proof the expansion of capitalism and eliminate challenge to it from the non-commodified and democratic temporalities of education and scientific discovery, however, international economic organisations have created policies, technologies and devices which close off possibilities for democratic educational politics in the future. Classifying higher education as a marketable 'service industry', for example, removes it from the anticipatory practices and norms of public service and creates a new 'cognitive frame' for higher education as belonging to a world of economic value, commodification, competition, risk, growth and survival. Through a careful analysis of key policy documents and devices for policy implementation, Robertson reveals how mechanisms within the General Agreement on Tariffs and Trade (GATT), the General Agreement on Trade in Service (GATS) and the Trade Related Intellectual Property Services (TRIPS) attempt to 'lock-in' capitalist futures by extracting nation-states' commitment to 'progressive liberalisation' (endless free market behaviour) in higher education in exchange for membership of the World Trade Organization.

Yet Robertson also reminds us that despite capital's powerful attempts to 'reframe, normalise and socialise' higher education as a globally tradeable commodity, mega-trade agreements have not been categorically successful. Initial efforts to impose this project were challenged. High-profile protests (such as the 1999 'Battle in Seattle'), numerous struggles in local 
institutions and communities, rights-based campaigns led by the $\mathrm{UN}$, and critical questions from government policy makers contributed to a slowdown of global negotiations by 2005 . However, Robertson argues that in the wake of the 2008 financial crisis, they were not only revivified but fortified. New mega-trade deals like the Trans-Pacific Partnership (TPP), Comprehensive Economic Trade Agreement (CETA), Transatlantic Trade and Investment Partnership (TTIP) and Trade in Services Agreement (TISA) not only aspire to colonise the future for academic capitalism, but are being negotiated in a 'more coercive, secretive approach to realigning interests' which protects the future from 'distributional struggles'. Against this global restructuring of higher education, Robertson affirms not only the value of political resistance but the importance of challenging this not-yet-common-sense through commitments to theory and practice that prioritise 'knowledge, openness, sharing and community as an alternative cognitive orientation toward the future'.

Yet political resistance in education needs strategies to effectively challenge futures of academic capitalism and develop new anticipatory stances toward the future. In 'Carpe the academy: dismantling higher education and prefiguring critical utopias through action research', Patricia Gayá and Mary Brydon-Miller introduce a 'radical methodology for prizing open and energizing democratic spaces' in which alternative educational futures can be imagined. Refusing to accept the 'dominant neoliberal paradigm' which permits the 'capture of the university by neoliberal logics to continue unabated', they argue that 'critical utopian action research' (Nielsen and Svenson 2006) can generate possibilities for reimagining and prefiguratively reclaiming the university as a democratic public good here and now. Like the design fictions of the Near Future School project, this method works within, against and beyond the repressive ontology of neoliberal power, making space for alternative futurities within and through the contradictions of this system. While readers may be familiar with both action research and prefigurative politics, Gayá and Brydon-Miller reach towards 'propulsive' utopias: imaginaries that produce radically alternative horizons by 'actualizing the utopian affects of hope and desire in the present moment'. In order to do so within university settings where technologies of performance management and datafication truncate the critical and democratic in everyday practice, critical utopian action research aims to 'confront and mitigate against differentials in power, and to expand the range of voices and subjectivities brought into such conversations'.

As in the Near Future School, this is an exercise in navigating complexity, contradiction and impossibility within hegemonic institutions. The expansion of future possibilities is understood here not as a matter of imagination or planning, but as a committed project of critical engagements with systemic power which creates enclaves of collective experimentation that aspire to large-scale, prefigurative transformation. The value of this approach is illustrated with examples of sustained community-university action research projects, international research-activist networks, cross-institutional teaching programmes, and global networks of researchers who aspire not to 'counter-hegemonic' change within the neoliberal ontology but to anti-hegemonic change that opens onto radically alternative higher education futures. 
The development of the capacity to engage and contest emergent futures is understood not as a marginal activity but as central to the democratic project of educating citizens, in 'Bridging anticipation skills and intercultural competences as a means to reinforce the capacity of global citizens for learning to learn together'. , Here, Iriana Lianaki-Dedouli and Jacques Plouin explore how integrating methods of foresight and 'intercultural competences' in future-oriented global citizenship education can expand possibilities for sustaining futures of peaceful co-existence in global society. They focus on how to overcome what they consider a global 'crisis in ...collective capacity to imagine common futures shared across borders and cultures', and to take action to realise them in public and in common. In particular, they argue that responsibility for the future is given over to and therefore colonised by institutions and professional elites, and that one purpose of global citizenship education is to minimise the risk of this colonisation. In order for this to be effective, however, the definition of citizenship must first be problematised and defined as a situation in which 'people have the power to define themselves or express who they are without limiting the capacity of others to do the same'.

Any education for citizenship, therefore, requires some form of 'educating for pluralism', and 'future-oriented pluralism' in particular. This attitude extends beyond national and discursive borders to embrace the challenges of co-creating common futures through agonistic (rather than antagonistic, following Mouffe 1998) deliberation about competing future visions. It also requires a special kind of 'intercultural competence' and its exercise in public. According to the UNESCO (2013) 'Conceptual and Operational Framework of Intercultural Competence', intercultural competences are 'abilities to adeptly navigate complex environments marked by a growing diversity of peoples, cultures and lifestyles'. Yet these do not yet include anticipatory competence. Lianaki-Dedouli and Plouin thus extend the concept for futures-oriented global citizenship education, offering new insights into how existing 'foresight' methodologies can facilitate the collective imagination and deliberation of global futures. The latter part of their paper reflects on an experimental application of four such approaches aiming to increase participation among young peace-building activists at a UNESCO-organised Pan-African forum in 2014, with the overall aim of shifting from 'teaching citizenship' to 'learning democracy'. While acknowledging the limits of this project created by the institutional context, they argue that combining participatory foresight and intercultural competence generated an 'exercise of empowerment, emerging from the realization by citizens that they can explore alternative futures, negotiate shared meanings and co-create new visions' - an outcome they call, following Bloch, 'educated hope'.

Whereas Lianaki-Dedouli's and Plouin's paper reflects on how democratic futures are debated in global peace-building, Sandra Kemp examines the historical power of the museum. 'Design museum futures, catalysts for education' considers the museum from two perspectives: historically, as a place of public pedagogy for imagining, constructing and fighting for the future; and currently, as a place for facilitating democratic deliberation about radical social alternatives in which competing futures are at play. Thinking from the intersection of design pedagogy, exhibition and social activism, the paper examines how design - which begins from the 'act of intentionally creating change' through selecting what is valuable, visible and discarded - has functioned to make different futures thinkable, 
particularly in the nineteenth-century British empire, in which 'time itself was under discussion'. Focusing on the South Kensington Museum (predecessor of the Victoria and Albert Museum), the Lahore Museum and Mayo School of Industrial Arts, and Imperial College London, Kemp illustrates how cultural value was articulated through 'the kinds of temporalities produced by different kinds of heritage', which in turn opened up different ways of thinking about the future. While this was accomplished in part through the design of exhibitions themselves, the museums were also active institutions of informal public learning, intellectual and artistic development, and the formation of the critical counter-publics. This was not without tensions, for it played an active role in both the advancement of the industrial revolution, arts and crafts movement and civic life in the colonial centre, and in the creation, legitimation and expansion of imperial division and power. The unique contribution of Kemp's article is to tease out the nuanced ways in which critical design practices can open space for imagining 'beyond the imperial project' and challenge the violences and exclusions of coloniality. Perhaps, she argues, critical design fictions can be 'possibility machines' and 'catalysts for social dreaming' in contemporary society.

In 'Hope and anticipation in education for a sustainable future', Maria Ojala outlines paths towards transformative anticipation in a different learning context: Education for Sustainable Development (ESD). While ESD is traditionally 'future-oriented', Ojala illustrates that in practice it does not necessarily help young people manage the complex emotions they often experience when attempting to imagine alternative futures in the face of global problems such as climate change, the loss of biodiversity and extreme social inequalities. Furthermore, even where specific elements of anticipation are taught, certain forms of ESD may in fact produce harmful forms of anticipatory emotion such as hopelessness and despair. These lead not to active engagement in struggles for sustainable environments and political systems, but to fatalism and detachment. Ojala therefore asks: how might anticipatory competences of hope be better incorporated into ESD, and more importantly, what kind of hope should this be?

To answer, she offers a map of varieties of hope - psychological, existential, critical and utopian - which she argues have different implications for critical agency. Drawing on an interdisciplinary literature on 'hope studies', she examines the potential of each to inform a transformative and mobilising ESD. Least facilitative is 'psychological' hope, defined as a positive cognitive and emotional attitude towards the future in situations where a person has clear goals and believes that there are plausible (if not possible) routes towards achieving them. This is unsatisfactory because it is individualised, abstracted from intersubjective action and emergent possibilities, and disconnected from broader economic, political and social conditions. 'Existential' hope, while also individualised, is not dependent on predetermined goals but on a generalised faith in oneself, others and the world. While this can be a superficial mode of hope, Ojala reminds us that it is the ontological basis for what critical theorists of possibility such as Ernst Bloch and Paulo Freire believed was the driving force of social change - the desire for a better world. This is also true of 'critical' hope, which, like existential hope, does not stem from or depend on known goals. It is rather grounded in concrete, material experience, particularly suffering. Here, hope is understood as the 'negation of the negative'; of that which offends life and possibility. An improvement on this, Ojala argues, is 'utopian, goal-oriented' hope. This form integrates the materiality of 
suffering, the articulation of (often non-realisable) goals for the future, and efforts to realise them through prefigurative practice, recognising the politics of these contested imaginaries. This type of hope is 'constructive' in that it is 'semi-realistic' and oriented not only towards building particular futures but also towards building confidence in the agency required for radical future-forming - including trust in others who are responsible for decisions. She illustrates this through classroom-based examples of pedagogies which enabled young people to explore strategies for encountering uncertain future scenarios, offering possibilities for hope to work in a transformative way. These experiences suggest that ESD pedagogies require both a 'critical stance towards hope' that is conducive to confident anticipatory practice, and a commitment to building relations of trust amongst intersubjectively responsible agents.

Taken together, these papers begin to trace a number of sites and practices through which educational orientations to the future might be reconstituted as creatively anticipatory rather than predictive, colonising and instrumental. They also document the reach and stability of economic and institutional practices that lock educational practice into a particular futurefacing position: the preparation of the neoliberal subject. Responding to this critique, they offer both theoretical resources and practical examples of how such a position can be traced and practices - from design fiction to critical utopian action research to the day to day working on museums, international trade agreements and school design - through which it might be, however temporarily, disrupted. Such disruption should be understood as a precondition for anticipatory educational moments, opening up space for the new to emerge even before it can be imagined or foreseen.

\section{References}

Adams, V., Murphy, M. and Clarke, A. (2009) 'Anticipation: technoscience, life, affect, temporality', Subjectivity, 28: 246-265.

Amsler, S. (2015) The Education of Radical Democracy, London: Routledge.

Barnett, R. (2013) The Future University, London: Routledge.

Bassey, M. (2011) Education for the Inevitable: Schooling when the Oil Runs Out, London: Book Guild.

Biesta, G. (2007) Beyond Learning, London: Routledge.

Dinerstein, A. C. (2014) The Politics of Autonomy in Latin America: The Art of Organising Hope, NY: Palgrave Macmillan.

Facer, K. (2011) Learning Futures: Education, Technology and Social Change, London: Routledge.

Gutiérrez Aguilar, R., Navarro Trujillo, M. and Linsalata, L. (2016) 'Producing the common and reproducing life: keys towards rethinking the Political' in Dinerstein, A. C. (ed.) Social Sciences for An Other Politics: Women Theorising without Parachutes, NY: Palgrave Macmillan. 
Miller, R. (2011) 'Being without existing: the futures community at a turning point? A comment on Jay Ogilvy's "Facing the fold"', Foresight, 13(4): 24-34.

Motti, V. (2017) 'Sources of Futures Studies from foresight to anticipation' in R. Poli (ed.) Handbook of Anticipation: Theoretical and Applied Aspects of the Use of Future in Decision Making, London: Springer.

Mouffe, C. (1998) 'Deliberative democracy or agonistic pluralism? Dialogue International Edition, 7/8: 9-21.

Nielson, K. and Svenson, L. (2006) Action and Interactive Research: Beyond Practice and Theory, The Netherlands: Shaker Publishing.

Osberg, D. (2010) 'Taking care of the future? The complex responsibility of education and politics.' In Osberg, D. and Biesta, G. (eds) Complexity Theory and the Politics of Education, Rotterdam: Sense Publishers.

Poli, R. (2017) Anticipation Science, New York: Springer.

Santos, B. d. S. (2014) Epistemologies of the South: Justice against Epistemicide, Boulder: Paradigm Publishers.

Smith, R. (2017) 'The emergence of the quantified child', Discourse, 38(5): 701-712.

\section{Notes}

1 The First International Conference on Anticipation took place from 5-7 November 2015 at the Department of Sociology and Social Research of the University of Trento with the support of UNESCO, the World Academy of Art and Science, the International Society for the Systems Sciences and the Advanced Design Network.

${ }^{2}$ Anticipation Studies may also be considered as part of the wider field of Futures Studies, which 'includes all the ways to study, think, and use the future - ranging from visionary and utopian futures to pop futures, from participatory, critical, or integral futures to the technicalities of simulations, formal modelling, and forecasting' (Motti 2017). 